International Journal of Linguistics, Literature and Translation

ISSN: 2617-0299 (Online); ISSN: 2708-0099 (Print)

DOI: $10.32996 /$ ijllt

Journal Homepage: www.al-kindipublisher.com/index.php/ijltt

IJLLT

\title{
A Pragmatic Study of Humor in Iraqi Facebook Comments
}

\author{
Zaid Najah Merzah \\ Assistant Lecturer, Faculty of Arts, Department of English, Imam Ja'afar Al-Sadiq University in Najaf, Iraq \\ Corresponding Author: Zaid Najah Merzah, E-mail: zaid.najah@sadiq.edu.iq
}

\author{
ARTICLE INFORMATION \\ Received: September 03, 2021 \\ Accepted: October 10, 2021 \\ Volume: 4 \\ Issue: 10 \\ DOI: $10.32996 /$ ijllt.2021.4.10.8
}

\section{KEYWORDS}

Pragmatics, humor, comments, cooperative principles, maxims

\section{ABSTRACT}

The main goal of this study is to determine how comments are made by Iraqis on Facebook (a social media platform) to express humor and to discover whether these comments follow specific linguistic principles or not. There are millions of humorous comments on different types of posts, but only political posts were chosen in this research because of the importance of these posts. In the writer's view, the politics of Iraq is greatly important as it dictates much of the situation that people currently live in. This means that there is also a lot of engagement by a lot of persons in Iraq with politics using humor, and there are therefore a large number of political posts using humor. This study relied on a specific method in analyzing data (namely comments selected from Facebook). 28 comments were selected for analysis by determining whether they follow the maxims of cooperative principles on the one hand and whether they follow any form of breaking of cooperative principles from another aspect. The arguments of Attardo were proven where he said that a person cannot be considered uncooperative in the conversation just because he said something funny or tried to be funny (Attardo, 2001). Moreover, the results showed that two forms of maxims of cooperative principle are followed several times, which are the maxims of relation and manner. It also showed that the least principle that is followed is the maxim of quality. There were also instances where maxims were not observed. It was found that the question of whether there would be flouting and violation of rules in the comments is most dependent on the commenter.

\section{Introduction}

Humor is a human feature that makes matters funny. Through this manner, humans adopt a farcical way of talking. According to language dictionaries, another definition of humor might be the capacity of laughing or being funny, particularly as expressed in literature or speech.

Patterns of laughter and amusement are classified so that certain patterns are socially appropriate. The philosophers selected the term "humor" and gave it a restricted and specialized meaning to distinguish these suitable expressions of laughter. Distinct from other laughter-related phenomena (e.g., wit, comedy, sarcasm, irony satire, ridicule), humor is now used to refer exclusively to a sympathetic, tolerant, and benevolent amusement at the imperfections of the world and the foibles of human nature generally as stated in (sense of humor, p.2). Furthermore, as discussed there have been different forms of humor, which can be based on cultural categories such as politics or social class. Psychologists have primarily dealt with humor to observe the incongruity and its resolution (e.g., Shultz \& Robillard, 1980; Suls, 1972). Therefore, a lot of humor appears in traditional riddles, comments and, jokes are based on ambiguity, that is, on a word or phrase that has more than one possible meaning and has been the subject of study (Robert \& William, p.59)

One of the main purposes of humor is to mock and belittle issues that cannot be criticized directly. For this reason, the interest of this research will focus on any form of humor that has been adopted in large quantities by Iraqi commentators commenting on the political sphere, looks at why humor is used in comments, and any method of linguistic that the commenters followed.

Copyright: (c) 2021 the Author(s). This article is an open access article distributed under the terms and conditions of the Creative Commons Attribution (CC-BY) 4.0 license (https://creativecommons.org/licenses/by/4.0/). Published by Al-Kindi Centre for Research and Development, London, United Kingdom. 


\subsection{Study Objectives}

The definition of humor has been discussed above. Humor is a phenomenon that has spread among Iraqis in recent years, and they use it as a way to express their views on various aspects of life, especially political aspects. Therefore, in light of linguistic studies of humorous comments, this research looks at similar use of humor, and we will show in this research if humorous comments that are made about political situations follow certain linguistic criteria such as cooperative principles of maxims or not.

This study is aimed at achieving the following objectives:

- Summarizing the results of previous studies about the topic.

- Providing a brief overview of the historical background of humor.

- Presenting a definition of humor and its types and forms in general.

- Presenting pragmatics definitions and providing a brief explanation of some of its fields, such as deixis, politeness, speech acts, implicature, and cooperative principles.

- Presenting a detailed explanation of the Cooperative Principle (CP) in conversation in general and the reference to its basic maxims.

- Analyzing the Iraqi humorous comments on Facebook and find out if they follow or violate the Gricean maxims.

This study is expected to be able to provide some significance both scientifically and theoretically because it is the first of its kind focusing on humorous comments made about political issues in Iraq. It is expected that this analysis is practically very significant for understanding the basic principles of humorous language. The study of these humorous phrases, words - inside a text - offers us some knowledge into how commentators express what they want to say, and therefore enables us to understand the pragmatic meaning of the text clearer. Further, this study will be beneficial to those interested in the fields of linguistics, literature, and stylistics as readers, writers, and critics.

\section{Literature Review}

Many studies have discussed the use of humor in language and analyzed and studied humor in all its aspects. In this research, we will summarize the results of some of these studies.

Ahdi Riyono (1979) discussed the topic of humor in a paper titled "Jokes as a Humor discourse: Pragmatic Study". He mentioned that humor is a violation of the communicative principles of pragmatics, in both its written and spoken aspects. Therefore, it is important to understand the theories of pragmatics, especially the principles of politeness to create socially acceptable humor.

Nawal F. Abbas \& Sura Dhiaa (2016) in their study titled "A Pragmatic Study of Humor" concluded that the flouting, infringing, and violation of Gricean maxims have the possibility of creating humorous situations in certain contexts. The study has exposed that: sometimes, two maxims can be non-observed at the same time, and the maxim of relation is the most violated.

D. Samuel F. Joshua (2020) in his research "A Pragmatic Analysis of the Discourse of Humour and Irony in Selected Memes on Social Media" dealt with the topic of humor in social media. He tackled in his study the ludic function of language in the humorous and satirical discourse and focused mainly on the funny and satirical memes on Facebook, Twitter, and Instagram.

Antonio R. \& Paolo R. \&Davide B. 2011 examined humor especially in social media in their study titled "From Humor Recognition to Irony Detection: The Figurative Language of Social Media." They determined that no single feature of humor is distinctly humorous or ironic, but all of them together provide a useful linguistic inventory for detecting these types of figurative devices at the textual level.

Oyebola F.K. (2016) in his paper titled "A Night of a Thousand Laughs: A Pragmatic Study of Humour in Nigeria" concluded that perceived violations of cooperative maxims cause humor and it has been proven that Grice's cooperative principle is a condition to achieve successful conversation. However, in some situations, in order for people to try to achieve the purpose or carry out a special effect, they have to deviate from the principle consciously or unconsciously. In such circumstances when the cooperative principle and maxims are violated, we would not think speakers disobey the conversational rules or are noncooperative. On the contrary, they do implement principles from the other side of the coin, and there are humor births in the special conversation.

\subsection{Historical Overview}

The study of humor is a sub-part of the aesthetics study and therefore scientists and philosophers are interested in it. Plato is the first Greek philosopher that has studied the characteristics, nature of humor, and laughter. He pointed out that a lack of self- 
knowledge is caused by the absurd and argued that we are facing a mix of both delight and envy when we laugh at what is ridiculous in someone (Plato,1861).

Making a contradiction between concept and the real topic is the main component of humor. Humor is a scenic irony of something, creating a contradiction between reality and the concept by confusing one of them (Schopenhauer, 1909: 281).

According to Kant, humor is one of the types of frustrated expectations, which is combining separate things in our minds. As such, humor is a talent that means the ability to put oneself within a certain mental framework according to certain lines completely different from the known way (Kant, 1952: 203).

On the other hand, Hobbes agreed with the superiority theory in humor, where he pointed out that the sense of superiority of one's self on to others causes laughter. It is a result of our sense of victory compared to the weakness of others or with our previous losses (Hobbes, 1962: 46).

Another type of humor is relief theory appeared because of the development of psychology and psychological analysis. Freud was the exponent for such a theory, his main point being that we laugh when we are free from community constraints (Freud, 1976).

\subsection{Humor}

No single agreed definition of humor has been presented, despite many attempts by scientists to define it. It is impossible to have a perfect and clear definition of humor as Attardo (1994: 3) points out. However, according to Singh (2012: 65), humor has two meanings. First, Humor is the ability of a person to understand the intent of things that are funny or enjoyable. Second, It is defined as the human ability to express clever or entertaining senses. That is, the person who has these abilities is one of the funny categories of people. Generally, all ideas and things that are funny, amusing, and laughable can be called humor. Humor, like any field of linguistics, is influenced by culture. Types of humor are different depending on the environment and history in which they arise.

\section{a. Forms of Humor}

Martin (2007: 10) mentioned that there are many forms of humor that people perform and present in different ways and for various purposes. Humor is sometimes presented through media such as television, radio, newspapers, and comedy films. On the radio, the hosts give us humor, and we can hear it. On television, there are various forms of humor, such as sitcoms, comedy shows, humorous advertisements, and stand-up comedies. As for newspapers, there is always a section that contains comic and funny cartoons. There are also different forms of humor, such as humorous movies and entertaining books. Also, politicians, religious leaders, and motivational speakers use humor in their speeches and lectures. There is now arguably a new type of humor that appeared recently when the use of social networking sites became widespread, so we see humor everywhere on Facebook and other sites, either in the form of comic posts or comments.

(Martin, 2007: 11) says that humor and laughter that occur in everyday life arise spontaneously during speaking in normal relationships with others. Divided humor that occurs daily into three main types:

1. Jokes: They are humorous phrases or very short funny stories that were said previously and are transmitted by people among each other.

2. Spontaneous conversational humor: People say it deliberately during a speech and it can be either verbal or nonverbal.

3. Accidental or unintentional humor (Martin, 2007: 11).

\section{b. Functions of Humor}

In general, the function of humor is to make the listener laugh. Humor also has many social functions. Attardo (1994, 323-329) classifies the function of humor into four classes:

1. Social management: In this case, humor is a tool that facilitates interaction between members of a specific group of people and makes their bonding stronger (Attardo, 1994: 323).

2. Decommitment: (Attardo, 1994: 325) also says that decommitment is one of the humor functions, where the speaker denies any bad intention to say or his previous action that used humor when he/she receives a negative response from the listener. The speaker may protect her/his face by denying the negative effect of her/his utterance, through this function.

3. Mediation: If the speaker's statements are not socially accepted, he/she has the option to deny their sincerity by claiming that he was "only" joking (Attardo, 1994: 327). 
4. Defunctionalization: According to Attardo (1994: 328), The main function of language is to communicate and transmit information. When this function is canceled, the use of language is transformed for fun purposes. In different words, humor is used for leisure functions (Attardo, 1994: 329). For example:

A: What is the librarian's favorite color?

B: Read.

\section{c. Theories of humor}

Several theories have described, analyzed humor and its components, and its place in society. Humor has been interpreted based on several theories. psychological theories that classify humor as having aspects that affect health and spiritual theories interpreted humor as something vague and inexplicable according to (Smullyan, 1980). Several theories are common among researchers:

The first one is called the relief theory, It confirms that laughter is a tool used to relieve stress in difficult and frightening situations. Relief in terms of a humor theory is most commonly associated with Freud's work in Jokes and Their Relation to the Unconscious (1960).

The second theory is named Superiority theory, the main content of this theory is gloating about others or laughing and mocking their problems and tribulations, and the perpetrator feels victorious for that. Laughter occurs as a reaction to a feeling of 'sudden glory' agreeing with (Attardo, 1994: 52).

The last important theory is The incongruity theory, this theory indicates that humor comes in a place that does not cause laughter so that there is a contradiction between the term humor and the situation in which it is used. In other words, the elements should not be completely odd or the humor will not be perceived (Raskin, 1985: 31-32).

\subsection{What is Pragmatics?}

Meanings of statements can vary according to circumstances and contexts that pronounce or write through them, and this is the main attention of pragmatics studies such as those by Trask mentioned above (1999: 243).

Pragmatics is the study of the intended meaning of a specific word or utterance and taking into account that the context has an effect on what is said or written. In another word, Pragmatism is interested in the hidden meaning of words more than the dictionary meaning, Yule (1996: 3).

According to most language studies, meaning can be divided into two main types: Semantic and pragmatic meaning (there are secondary types that are not relevant for the purpose of this study). In semantics, the meaning is an integral part of a linguistic expression. On the other hand, in pragmatics, the meaning is a combination of the linguistic term and the context that is used in, and therefore looks at the way each one affects the other (Trask, 1999: 243).

There are some fields in pragmatics, like deixis, politeness, speech acts, implicature, and cooperative principles.

Deixis refers to "pointing via language" Yule (1996: 9). Deixis is words, pronouns, or phrases used by the speaker or writer for references to something. Deixis is separated into three types: person deixis, spatial deixis, and temporal deixis.

(Yule, 1996) state that politeness is the public self-image of a person and it is a kind of awareness.

Yule also declares there were actions performed by words called the speech acts (1996: 47). There are five types of speech acts like making statements, expressing feeling, giving commands, making a promise, or changing the world by utterance (Yule, 1996: 5354).

Another aspect of pragmatics is implicature, which uses non-direct declaration in speech. In this, the speaker intends to carry more meanings than has been said. In another word, implicature is a meaning that the speaker or writer wants to deliver it for the listener or reader without a direct permit (Horn, 2006: 3).

Grice (1975: 45) claims that the conduct of discussion is guided by a set of assumptions. Grice describes four fundamental conversational maxims that underpin effective cooperative language use, which he refers to as the Cooperative Principle (CP).

\subsection{The Pragmatics of Humor}

Grice, 1975 describes humor as a violation of the cooperative Principle (CP). Some communication methods are socially unacceptable because they break the CP-like deception and lying. However, humor is different. Although the speaker breaks the $\mathrm{CP}$, the community agrees with this violation because its purpose is laughter and entertainment. Just because the speaker tells a joke or tries to be funny, one cannot say that the speaker breaks the maxims of the cooperative principles(Attardo, 2001: 4). 


\subsection{Cooperative Principles}

Grice (1975: 45) mentions that there is a group of principles that must be followed when holding a conversation, and these principles may be formulated as guidelines for efficient and effective use of language. According to Grice, there are four basic maxims of conversation which together express a general Cooperative Principle. During the talk exchange, a speaker must give a contribution as is required and in line with the context where she/he is engaged. The maxims are quality, quantity, relation, and manner. There are two ways to follow these maxims. The first way is doing an observance of maxim and the other is doing a nonobservance of maxim. If the speaker observed these maxims successfully this is called observance of maxim. Meanwhile, when the speaker fails to observe maxim, it is called non-observance of maxim.

\section{A. Observance of Maxim}

When the speaker follows four maxims in the perfect way to achieve effective conversation, the observance of the maxim happens. Grice (1975: 45-46) classify the four maxims as follow:

(1) Maxim of Quality

The maxim of Quality does not permit the speaker to mention something that is believed to be incorrect and something that lacks good enough evidence (Grice, 1975: 46). In another way, the speaker is supposed to be honest and explicit.

A: Why you did not succeed in the exam?

B: Because I did not study very well.

(2) Maxim of Quantity

In this maxim, the speaker is requested to say no more or less than is required in conversation (Grice, 1975: 45).

A: What are you eating?

B: An Apple.

(3) Maxim of Relation

In this maxim, the speaker is requested to say something that is relevant to what has been said before (Grice, 1975: 46).

A: Did you know why the manager did not come today?

B: Because he is sick.

(4) Maxim of Manner

The maxim of Manner requires the speaker to explain matters orderly and clearly (Cutting, 2002: 35). In addition, it requires the speaker to keep away from obscurity of expression, avoid ambiguity, be brief, and be orderly (Grice, 1975: 46).

A: Where was Ali this evening?

B: He went to the library and bought some books to complete his research.

\section{B. Non-Observance of Maxim}

There are four methods of not following maxims: opting out, violating, infringing, and flouting (as set out by Cutting, (Cutting, 2002: 36-41)). Non-observance of maxims occurs when the speaker fails to observe a maxim.

(1) Opting out

When she/he is unwilling to cooperate, the speaker is opting out of a maxim. Sometimes for legal or ethical reasons, the speaker cannot respond in the manner expected. For example: When criminals are caught, we usually hear this phrase from the police officer:

The journalist asked: what is the name and identity of the criminal sir?

The police officer: I am sorry I cannot permit to say that now.

(2) Violating

(Cutting, 2002: 40) mention that the speaker deliberately provides incorrect, insufficient, or non-existent information, and the hearer wrongly assumes that they are cooperating. Cutting also states that violating a maxim is often with the intention to mislead or deception. 
A: Does your dog bite?

B: No .

A: (Bends down to stroke it and gets bitten) Ow! You said your dog doesn't bite!

B: That isn't my dog.

(Cutting, 2002: 40).

(3) Infringing

Cutting (2002: 41) states that the maxims are infringed by the speaker because of her/his imperfect linguistic performance. In other words, a speaker infringes the maxims when he/she has an imperfect knowledge or performance of languages, like a learner of a foreign language or a young child. As shown in the example below:

English speaker: would you like tea or lemon juice?

Non-English speaker: yes.

(4) Flouting

When a speaker intentionally fails to follow a maxim in which she/he has certain purposes, maxim flouting happens. (Cutting, 2002: 37). The speaker wants to inform the implicit meaning that differs from or in addition to the meaning expressed. Types of flouting are quality, quantity, relation, and manner. That is, flouting can be through the manner, the quantity, the quality, and the relation.

\section{Methodology and Data Collection}

The data for this study were taken from Iraqi Facebook comments on various types of political posts. These comments were obtained through a screenshot over a period of two years (2020/2021) by the researcher who is an active user on Facebook. Twenty-eight (28) comments were intentionally selected for pragmatic analysis using the Maxims of the cooperative principle. The cooperative principles were used in analyzing comments to indicate whether or not they follow CP. Over 50 comments were obtained at the start of the study and after applying the criterion for including comments in this study 28 suitable comments were identified. The main criterion for identifying a suitable comment was its humorous nature, which concerned various political topics only. The comments that were excluded were comments that had a sense of humor but were not on political issues.

This study is based on an analysis of humorous comments related to political matters. Through this research, we discover that the percentage of men who post sarcastic comments on Facebook is more than women. This may be because of Iraqi women's personality in general, which is often characterized by shyness, which prevents her from commenting in a humorous manner, and this is what made finding a funny or comic women's comment difficult. This study contains one comment for a girl compared to 27 comments for young people in general. This is likely due to the fact that Iraqi young men are in general bolder to make such comments in society, which does not prevent him from saying anything funny in various situations, especially political ones. In the table below, the first column shows the post that was commented on. the second column presents the sequence of comments, the third column presents the image and of the comments. The fourth column shows which observance of Maxim has been followed, the fifth column shows non -observance of Maxim has been followed, And the sixth column shows a pragmatic linguistic analysis of the comments.

\begin{tabular}{|c|c|c|c|c|c|}
\hline The post & $\begin{array}{l}N \\
0\end{array}$ & The comments & $\begin{array}{l}\text { Observance } \\
\text { of Maxim } \\
\text { that has } \\
\text { been } \\
\text { followed }\end{array}$ & $\begin{array}{l}\text { Non } \\
\text {-Observance } \\
\text { of Maxim } \\
\text { that has been } \\
\text { followed }\end{array}$ & $\begin{array}{l}\text { Pragmatic explanation of } \\
\text { comments }\end{array}$ \\
\hline & 1. & $\begin{array}{l}\text { Lola oucen } \\
\text { Do they have another } \\
\text { sheikh? }\end{array}$ & $\begin{array}{l}\text { Quantity } \\
\text { Relation } \\
\text { Manner }\end{array}$ & Flouting & $\begin{array}{l}\text { The commentator here uses the } \\
\text { word "Zayed" (Sheikh of the } \\
\text { UAE) which means (another) in } \\
\text { the Iraqi dialect to indicate } \\
\text { whether the Emiratis have } \\
\text { another sheikh to introduce to } \\
\text { Iraq. }\end{array}$ \\
\hline
\end{tabular}




\begin{tabular}{|c|c|c|c|c|c|}
\hline 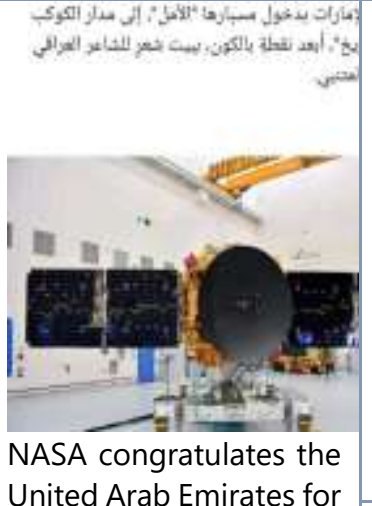 & 2. & $\begin{array}{l}\text { We also launched the Iraqi } \\
\text { probe in 2006, but we do not } \\
\text { know where it has reached } \\
\text { until now. }\end{array}$ & Relation & Violating & $\begin{array}{l}\text { In a humorous way, this } \\
\text { comment responds to the post } \\
\text { with fabricated news, in terms } \\
\text { of launch where the bombing } \\
\text { of the mosque was likened to } \\
\text { sending the probe into space. } \\
\text { As the situation in Iraq in } 2006 \\
\text { was dominated by terrorism } \\
\text { and murder, and Iraq did not } \\
\text { reach a stage of development } \\
\text { that would allow it to send } \\
\text { probes into space. }\end{array}$ \\
\hline $\begin{array}{l}\text { the entry of its "Hope" } \\
\text { probe into the orbit of } \\
\text { Mars. }\end{array}$ & 3. & $\begin{array}{l}\text { I am sure if we had this plate, } \\
\text { we would have put it on a } \\
\text { satellite or put chicken food } \\
\text { in it. }\end{array}$ & $\begin{array}{l}\text { Relation } \\
\text { Quantity } \\
\text { Manner }\end{array}$ & Flouting & $\begin{array}{l}\text { Here the comment describes } \\
\text { the dish on the spacecraft as a } \\
\text { dish for storing chicken food in } \\
\text { a sarcastic way. It indicates that } \\
\text { these technologies cannot be } \\
\text { developed in Iraq. }\end{array}$ \\
\hline & 4. & $\begin{array}{l}\text { On the right is a live } \\
\text { broadcast between the } \\
\text { spacecraft and planet earth, } \\
\text { and on the left is a video call } \\
\text { inside Iraq. }\end{array}$ & $\begin{array}{l}\text { Quality } \\
\text { Relation } \\
\text { Manner }\end{array}$ & Flouting & $\begin{array}{l}\text { This comment has a link to the } \\
\text { post in terms of sending the } \\
\text { spacecraft, but the } \\
\text { commentator shared his } \\
\text { information for the purpose of } \\
\text { demonstrating the weakness of } \\
\text { the Internet network in Iraq and } \\
\text { its strength in the spacecraft. } \\
\text { We can conclude that if the } \\
\text { Internet in Iraq is like this and } \\
\text { this is the simplest thing, then } \\
\text { how can Iraq send a spacecraft? }\end{array}$ \\
\hline & 5. & $\begin{array}{l}\text { Electricity directorate to } \\
\text { complain. I found them using } \\
\text { the home generator. I was } \\
\text { ashamed to talk to them } \\
\text { about it. }\end{array}$ & $\begin{array}{l}\text { Manner } \\
\text { Quantity }\end{array}$ & Flouting & $\begin{array}{l}\text { This comment has nothing to } \\
\text { do with the post, but Iraqi } \\
\text { commentators are used to } \\
\text { commenting with humor sense, } \\
\text { even if it is irrelevant. This } \\
\text { comment shows that the } \\
\text { electrical power center in Iraq } \\
\text { does not own it. }\end{array}$ \\
\hline
\end{tabular}




\begin{tabular}{|c|c|c|c|c|c|}
\hline $\begin{array}{l}\text { In Egypt, a pharaonic } \\
\text { royal procession was } \\
\text { transported, carrying } \\
\text { the mummy of } 22 \text { of the } \\
\text { kings and queens of the } \\
\text { great pharaohs, in } \\
\text { majestic ceremonies } \\
\text { that had never } \\
\text { happened before. }\end{array}$ & 6. & $\begin{array}{l}\text { Like Egypt, we also have relics } \\
\text { of the kings of Assyria, but we } \\
\text { put them in boxes because } \\
\text { they are humble kings, not } \\
\text { like the kings of the arrogant } \\
\text { Egyptians, who are } \\
\text { transported in cars and an } \\
\text { official reception }\end{array}$ & $\begin{array}{l}\text { Relation } \\
\text { Manner } \\
\text { Quantity }\end{array}$ & Flouting & $\begin{array}{l}\text { This comment mocked the Iraqi } \\
\text { method of preserving } \\
\text { antiquities compared to the } \\
\text { high-level Egyptian method. } \\
\text { The commentator used a } \\
\text { serious but sarcastic } \\
\text { commentary method to } \\
\text { demonstrate the humorous } \\
\text { intent of the comment. }\end{array}$ \\
\hline $\begin{array}{l}\text { The Iraqi Prime Minister } \\
\text { and his accompanying } \\
\text { delegation perform the } \\
\text { Umrah rituals. }\end{array}$ & 7. & $\begin{array}{l}\text { We fear that the Black Stone } \\
\text { will be stolen and Iraq will } \\
\text { continue to pay } \\
\text { compensation to Saudi } \\
\text { Arabia for } 30 \text { years. }\end{array}$ & $\begin{array}{l}\text { Relation } \\
\text { Quantity }\end{array}$ & Violation & $\begin{array}{l}\text { In this comment, there is a } \\
\text { serious accusation to what was } \\
\text { referred to in the post, as it is a } \\
\text { clear violation, but in a } \\
\text { humorous way that combines } \\
\text { reality and impossibility. }\end{array}$ \\
\hline $\begin{array}{l}\text { A businessman } \\
\text { detained in the Anti- } \\
\text { Corruption Committee, } \\
\text { recognizes deputies and } \\
\text { officials through whom } \\
\text { he succeeded in } \\
\text { concluding huge } \\
\text { contracts and deals in } \\
\text { the Ministries of } \\
\text { Electricity and Industry. }\end{array}$ & 8. & $\begin{array}{l}\text { Hathan althald } \mathbf{C} \\
\text { A crow says to another crow } \\
\text { that your face is black. }\end{array}$ & $\begin{array}{l}\text { Quality } \\
\text { Quantity } \\
\text { Manner }\end{array}$ & $\begin{array}{l}\text { Flouting } \\
\text { Violation }\end{array}$ & $\begin{array}{l}\text { Here the commentator uses an } \\
\text { old saying that violates the } \\
\text { published topic. The } \\
\text { commentator described the } \\
\text { corrupt businessman who } \\
\text { described some dishonest } \\
\text { officials as crow-like and sets } \\
\text { out that he is equal to them in } \\
\text { dishonesty and betrayal. }\end{array}$ \\
\hline
\end{tabular}




\begin{tabular}{|c|c|c|c|c|c|}
\hline 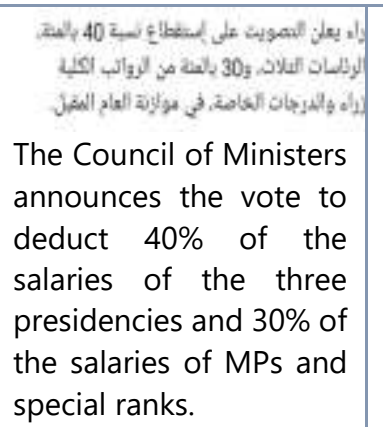 & 9. & $\begin{array}{l}\text { The decision is in the hands of } \\
\text { the Parliament. Imagine that } \\
\text { you are telling the deputy } \\
\text { that we will cut off your } \\
\text { salary, Does he vote yes, for } \\
\text { example? }\end{array}$ & $\begin{array}{l}\text { Quality } \\
\text { Quantity } \\
\text { Relation } \\
\text { Manner }\end{array}$ & $\begin{array}{l}\text { Violation } \\
\text { Flouting }\end{array}$ & $\begin{array}{l}\text { The commentator mocks the } \\
\text { post directly, as human } \\
\text { tendency does not allow } \\
\text { anyone to take part of their } \\
\text { money, no matter how much, } \\
\text { So the commentator asks in a } \\
\text { humorous way if he asks the } \\
\text { House of Representatives to } \\
\text { vote on deducting their } \\
\text { salaries, will they agree? }\end{array}$ \\
\hline
\end{tabular}

\begin{tabular}{|c|c|c|c|c|c|}
\hline Iraq records the highest daily & 10. & 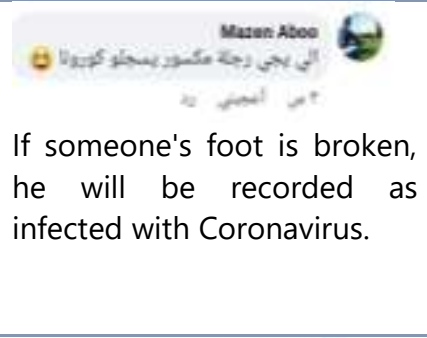 & $\begin{array}{l}\text { Quantity } \\
\text { Manner }\end{array}$ & flouting & $\begin{array}{l}\text { The huge number of infections } \\
\text { with Coronavirus made the } \\
\text { commentator not believe that } \\
\text { these numbers are real. It is } \\
\text { believed that any sick that enters } \\
\text { the hospital records Corona } \\
\text { infection whether they really had } \\
\text { the infection or not. }\end{array}$ \\
\hline $\begin{array}{l}\text { reached } 8,331 \text { cases of } \\
\text { Coronavirus within } 24 \text { hours. }\end{array}$ & 11. & 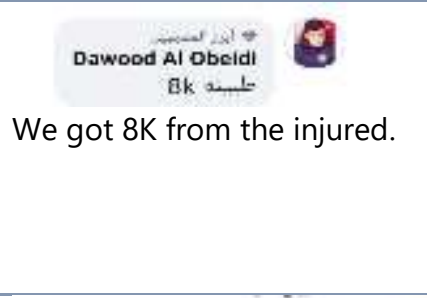 & $\begin{array}{l}\text { Manner } \\
\text { Relation }\end{array}$ & flouting & $\begin{array}{l}\text { Such as the method of counting } \\
\text { followers on social networking } \\
\text { sites is calculated by (k) for every } \\
\text { thousand people. Here the } \\
\text { commentator described that } \\
\text { injuries exceeded } 8 \mathrm{k} \text { (eight } \\
\text { thousand). }\end{array}$ \\
\hline 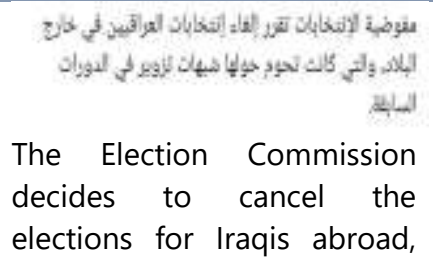 & 12. & 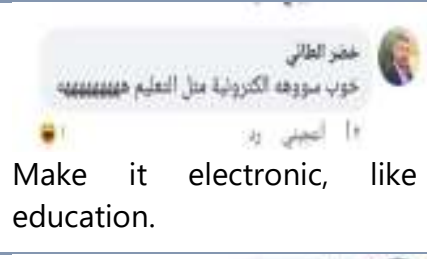 & $\begin{array}{l}\text { Relation } \\
\text { Manner }\end{array}$ & Violation & $\begin{array}{l}\text { The commentator here mocks } \\
\text { the elections and their integrity, } \\
\text { as he asks to make them } \\
\text { electronic, like education, the } \\
\text { attempt to which to turn them } \\
\text { into electronic was a failure. }\end{array}$ \\
\hline $\begin{array}{l}\text { which were suspected of } \\
\text { fraud in previous rounds. }\end{array}$ & 13. & Elections.... & $\begin{array}{l}\text { Relation } \\
\text { Manner } \\
\text { Quantity }\end{array}$ & $\begin{array}{l}\text { Opting } \\
\text { out }\end{array}$ & $\begin{array}{l}\text { The commentator chose the } \\
\text { answer in one word(Elections) } \\
\text { with a laughing emoji that } \\
\text { summed up the lack of integrity } \\
\text { in the elections and the pre- } \\
\text { determined results. }\end{array}$ \\
\hline $\begin{array}{l}\text { With wearing a mask for fear } \\
\text { of catching Corona, } \\
\text { thousands of shots were fired }\end{array}$ & 14. & $\begin{array}{l}\text { Now the State of Kuwait has } \\
\text { entered an ultimatum and } \\
\text { fled to Saudi Arabia. }\end{array}$ & Manner & violating & $\begin{array}{l}\text { Due to the insecurity in the } \\
\text { southern regions of Iraq and the } \\
\text { spread of indiscriminate gunfire } \\
\text { on occasions, the commentator } \\
\text { has joked that perhaps Kuwait, } \\
\text { the neighboring state of Iraq } \\
\text { from the south, fled to Saudi } \\
\text { Arabia because of the sounds of } \\
\text { gunfire. }\end{array}$ \\
\hline $\begin{array}{l}\text { randomly at the funeral of a } \\
\text { businessman in Basra who } \\
\text { died due to the pandemic. }\end{array}$ & 15. & $\begin{array}{l}\text { Aren't there reward missiles } \\
\text { for the late soul, this is not }\end{array}$ & Relation & $\begin{array}{l}\text { Flouting } \\
\text { Violating }\end{array}$ & $\begin{array}{l}\text { Here, the commentator asked } \\
\text { about a dangerous case in a } \\
\text { comical way if there were missiles } \\
\text { launching them on this occasion, } \\
\text { and he continues his sarcastic }\end{array}$ \\
\hline
\end{tabular}




\begin{tabular}{|c|c|c|c|c|c|}
\hline & & $\begin{array}{l}\text { enough. RPGs will also serve } \\
\text { the purpose. }\end{array}$ & & & $\begin{array}{l}\text { way that RPGs or any kind of } \\
\text { missiles are acceptable. }\end{array}$ \\
\hline 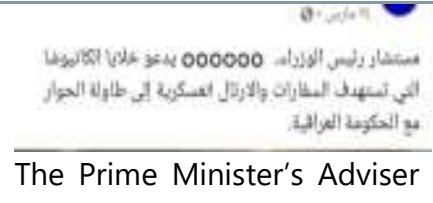 & 16. & $\begin{array}{l}\text { Do they come alone or with } \\
\text { rockets? }\end{array}$ & Relation & flouting & $\begin{array}{l}\text { The commentator also } \\
\text { humorously indicated whether } \\
\text { the missiles themselves would } \\
\text { attend the meeting or not }\end{array}$ \\
\hline $\begin{array}{l}\text { The Prime Minister's Adviser } \\
\text { invites the Catyusha cells that } \\
\text { target embassies and military } \\
\text { convoys to the conversation } \\
\text { table with the Iraqi } \\
\text { government. }\end{array}$ & 17. & $\begin{array}{l}\text { They want to catch them } \\
\text { under the pretext of } \\
\text { conversation and then arrest } \\
\text { them, don't you understand } \\
\text { that? }\end{array}$ & $\begin{array}{l}\text { Relation } \\
\text { Manner }\end{array}$ & $\begin{array}{l}\text { Flouting } \\
\text { violating }\end{array}$ & $\begin{array}{l}\text { This commentator gave a funny } \\
\text { reason for this meeting, as he } \\
\text { indicated that there is a plan to } \\
\text { arrest the militants and set a trap } \\
\text { for them under the pretext of the } \\
\text { meeting. }\end{array}$ \\
\hline $\begin{array}{l}\text { Al-Karkh health: a large } \\
\text { abstention among health } \\
\text { personnel from taking the } \\
\text { Chinese Sinopharm vaccine. }\end{array}$ & 18. & $\begin{array}{l}\text { Salam M. Khboor } \\
\text { The vaccine must be tried on } \\
\text { high-ranking officials in Iraq } \\
\text { first. If they survive, the } \\
\text { vaccine is safe, And if they die, } \\
\text { Iraq is safe. }\end{array}$ & Relation & violating & $\begin{array}{l}\text { In a cynical way and sometimes } \\
\text { seems serious, this commentator } \\
\text { indicated that the vaccine must } \\
\text { be tried on politicians and } \\
\text { officials, and if its failure is proven } \\
\text { by their death, Iraq will be safe } \\
\text { from corruption and theft } \\
\text { because of them. }\end{array}$ \\
\hline \multirow[t]{2}{*}{ 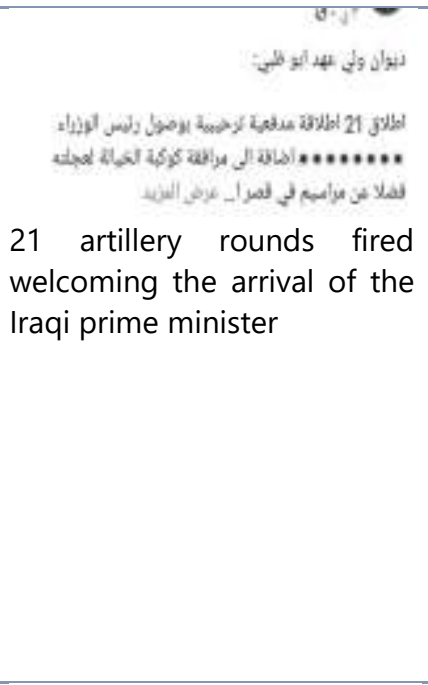 } & 19. & $\begin{array}{l}\text { Why do you criticize the clans } \\
\text { when they throw bullets to } \\
\text { receive the VIPs? These heads } \\
\text { of state do more than that. }\end{array}$ & $\begin{array}{l}\text { Relation } \\
\text { Manner } \\
\text { Quality }\end{array}$ & flouting & $\begin{array}{l}\text { Here is a funny question, why do } \\
\text { we criticize the clans when they } \\
\text { shoot bullets, and this is a head } \\
\text { of state throwing cannons at } \\
\text { official receptions. }\end{array}$ \\
\hline & 20. & $\begin{array}{l}\text { Saudi Arabia and the UAE } \\
\text { always welcome us with guns. } \\
\text { Is it the prime minister or the } \\
\text { prayer for Iftar? }\end{array}$ & $\begin{array}{l}\text { Relation } \\
\text { Manner }\end{array}$ & flouting & $\begin{array}{l}\text { This comment likens the prime } \\
\text { minister to the prayer for Iftar } \\
\text { wherever he goes, firing cannons } \\
\text { to greet him. }\end{array}$ \\
\hline 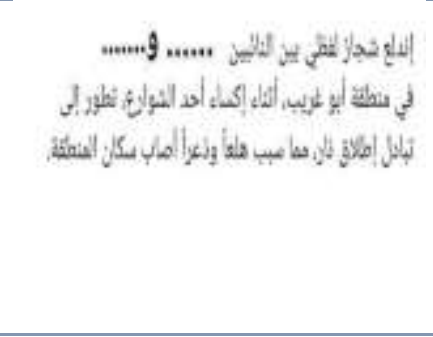 & 21. & 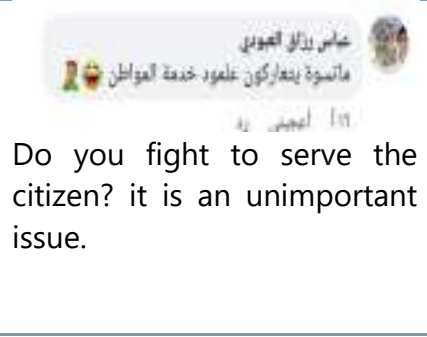 & Relation & Violating & $\begin{array}{l}\text { In a desperate and cynical way, } \\
\text { this comment indicates that } \\
\text { serving the citizen is not } \\
\text { important for politicians to fight } \\
\text { over it, because their quarrels } \\
\text { have always been over positions } \\
\text { and implementation and not a } \\
\text { race to serve the citizen }\end{array}$ \\
\hline
\end{tabular}




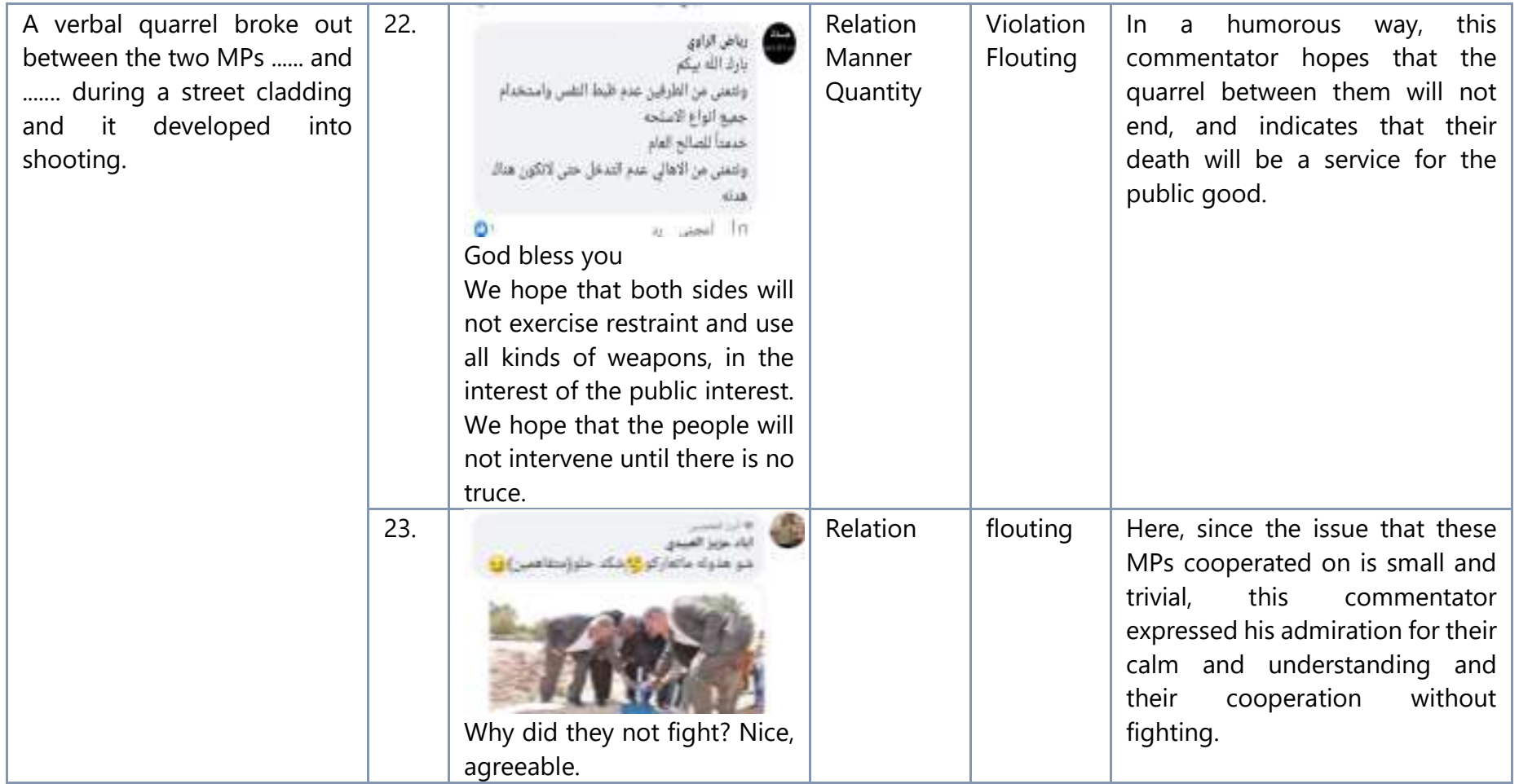




\begin{tabular}{|c|c|c|c|c|c|}
\hline \multirow[t]{3}{*}{$\begin{array}{l}\text { North Korea's leader ordered } \\
\text { the execution of a high-ranking } \\
\text { official for violating health } \\
\text { guidelines. }\end{array}$} & 24. & $\begin{array}{l}\text { We need you in Iraq on } \\
\text { Thursdays and Fridays. }\end{array}$ & $\begin{array}{l}\text { Manner } \\
\text { Quantity }\end{array}$ & $\begin{array}{l}\text { Violation } \\
\text { Flouting }\end{array}$ & $\begin{array}{l}\text { This commentator wants to } \\
\text { point out that failure to adhere } \\
\text { to health guidelines is } \\
\text { widespread in Iraq, so he asks, } \\
\text { in a cynical way, from the } \\
\text { Korean president to come to } \\
\text { Iraq on holidays in which large } \\
\text { gatherings take place to kill } \\
\text { anyone who violates the health } \\
\text { instructions }\end{array}$ \\
\hline & 25. & $\begin{array}{l}\text { When they carry out the } \\
\text { death sentence, they tell him } \\
\text { that they executed him for his } \\
\text { benefit so that he would not } \\
\text { die in Corona. }\end{array}$ & $\begin{array}{l}\text { Relation } \\
\text { Manner }\end{array}$ & Violating & $\begin{array}{l}\text { This commentator explains the } \\
\text { reason for the execution of the } \\
\text { death sentence in a very } \\
\text { humorous way, as they } \\
\text { executed him in order not to } \\
\text { die due to complications from } \\
\text { the Coronavirus. }\end{array}$ \\
\hline & 26. & $\begin{array}{l}\text { That is, if he were in Iraq, only } \\
5 \text { people would remain alive. }\end{array}$ & $\begin{array}{l}\text { Relation } \\
\text { Quantity }\end{array}$ & Violating & $\begin{array}{l}\text { The commentator indicates in } \\
\text { a humorous way that most of } \\
\text { the Iraqi people are not } \\
\text { committed to the health } \\
\text { guidelines for the prevention } \\
\text { of Coronavirus, so if such } \\
\text { provisions are applied in Iraq, } \\
\text { only five people will remain } \\
\text { alive. }\end{array}$ \\
\hline 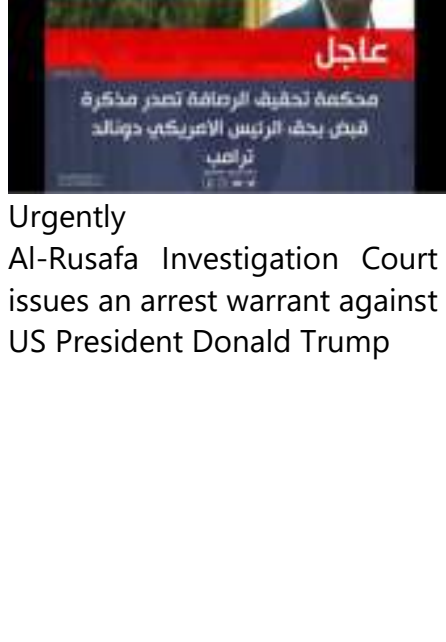 & 27. & $\begin{array}{l}\text { For his part, the outgoing US } \\
\text { President stressed ...... } \\
\text { He is ready to appear before } \\
\text { the Iraqi judiciary...... } \\
\text { It is noteworthy that the } \\
\text { police detachments are } \\
\text { conducting searches for the } \\
\text { accused Trump and his } \\
\text { defunct regime men in the } \\
\text { neighborhoods and alleys of } \\
\text { New York... }\end{array}$ & $\begin{array}{l}\text { Relation } \\
\text { Manner } \\
\text { Quantity }\end{array}$ & flouting & $\begin{array}{l}\text { In a very cynical way, he } \\
\text { narrated the news in a way as if } \\
\text { it were true, and in this way, he } \\
\text { indicated the impossibility of } \\
\text { arresting the American } \\
\text { president by the Iraqi judiciary. }\end{array}$ \\
\hline & 28. & $\begin{array}{l}\text { A copy of the news to. } \\
\text { NYPD to take action and } \\
\text { inform us of the results }\end{array}$ & Relation & Flouting & $\begin{array}{l}\text { This comment also took a } \\
\text { cynical turn as he asked the } \\
\text { New York Police to take the } \\
\text { necessary measures in a } \\
\text { humorous way, as emojis } \\
\text { indicated that. And the } \\
\text { impossibility of this happening } \\
\text { in reality. }\end{array}$ \\
\hline
\end{tabular}

\section{Analysis and Discussion}

The title of this research is a pragmatic study of humor in Iraqi Facebook comments. Since pragmatics is a very broad field of linguistics, we have chosen to analyze comments according to maxims of cooperative principles only. Comments are responses to 
specific posts in their nature, absolutely, a response to specific words, sounds, videos, in this sense that Facebook comments are similar in one way or another to the daily conversations and this is a kind of conversations that Maxims are concerned with. Because the maxims are the principles of analyzing the conversations, we relied on the maxims to analyze the comments in this research.

The commentators in the above comments were consciously or unconsciously interested in following some principles of cooperation frequently, and there are some principles that they did not care to follow very much. For example, the commentators were interested in following the maxim of relation a lot, as 23 of the 28 comic comments followed this principle with caution. They kept the comment linked to the topic of the original post, but at the same time, they made a comment that is humorous in nature. While the following maxim of quantity and manner was in close proportions, the repeat of quantity maxim was 13 of 28 times and manner maxim was 19 times. However, following the maxim of quality was not common, as it was followed in only 4 comments out of 28 comments. This is deduced as when following this maxim, the comment must be free from false or lack of evidence as set out (Yule 2017) and this cannot be proven in the comments. The chart below summarizes the results:

\begin{tabular}{|l|l|}
\hline $\begin{array}{l}\text { Observance of Maxim that has } \\
\text { been followed }\end{array}$ & $\begin{array}{l}\text { The number of } \\
\text { times followed }\end{array}$ \\
\hline the maxim of relation & 23 \\
\hline the maxim of manner & 19 \\
\hline the maxim of quantity & 13 \\
\hline the maxim of quality & 4 \\
\hline
\end{tabular}

On the other hand, this study has shown the non-observance of maxims that the commenters have followed. A large proportion of the comments flouted and violated the maxims. Where the flouting was followed in 19 comments, and the violating was cared about in 14 comments out of 28. As for the principle of opting out, it was followed only once. As the principle of infringing was concerned, it was not found any example of a humorous comment on a political post that follows this principle, due to the difficulty of finding such humorous kinds of comments. The chart below summarizes the results:

\begin{tabular}{|l|l|}
\hline $\begin{array}{l}\text { Non- Observance of Maxim } \\
\text { that has been followed }\end{array}$ & $\begin{array}{l}\text { The number of times } \\
\text { followed }\end{array}$ \\
\hline Flouting & 19 \\
\hline Violating & 14 \\
\hline Opting out & 1 \\
\hline Infringing & 0 \\
\hline
\end{tabular}

Overall, the analysis of the data showed that the comments on these posts were laughable and not the kind of response the poster expected. Most of the comments show some form of contradiction between the comment and the post, and most of them followed the style of verbal sarcasm. The researchers have agreed that a text that is humorous text should be fun and show some form of contradiction, at least as explained by Attardo (2017) in The General Theory of Verbal Humor.

All comments analyzed in this study have the (target) principle. The (target) principle states that a (superior) person can "attack" and attempt to modify the behavior of an (inferior) person. That is, the topics of the posts on Facebook are inferior, while the commented people are superior. Thus, the responses and comments used humor as a means of attack, as indicated by Atardo (2017), it is an attempt to modify the thinking pattern of the inferior person ( the poster, the post's idea). This 'attack' on the posters can be obviously seen from the commenters in data $2,4,5,6,7,8,15,18,22,27$, and 28 . The joke has a message that has the verbal or contradictory skill, that is, it can achieve the goal and provoke laughter at the same time by playing on words and their usings, and use words that have similar and different meanings at the same time in a different situation as in data no. 1.

For many years, Iraqis have been accustomed to using humor in the face of the difficulties they live in. There are many calamities and adversities in Iraq. It is therefore arguable that Iraqis have replaced sadness with laughter and humor in several situations. A lot of means of expression became active, relying on humor and irony since 2003 and right now. Saleh Al-Hamdani, an Iraqi journalist, says that humor and irony are an integral part of our daily interactions as human beings around the world. Al-Hamdani, who is known for using irony and humor as a framework for social criticism, says that humor is a communication tool that puts the reader, writer, and topic in one human fold, meaning that no one feels that he is not subject to criticism and does not feel disturbed by the volume of criticism. He also said that any thought in your mind could be communicated in the fastest way possible using humor and sarcasm. That is, humor prolongs the life cycle of the information that the writer wants to present, in other words, that the information or idea remains entrenched in memory for a longer period and is exchanged among others if it is in a humorous way more than if it is in a serious way. 


\section{Conclusion}

This study aimed at presenting humor as a linguistic phenomenon and analyzing humorous comments used by Iraqis when commenting on issues related to politics. The study also examined whether these comments followed or violated the Gricean maxims.

It has been concluded that Iraqis use humor to a large extent as a form of protest against the current political situation. The reason Iraqis use humor and satire in Facebook comments is to cover up the dire conditions in the country. The research found that the use of humor by Iraqis spread widely after 2003, after openness to the world and social networking sites, as it was not previously present in Iraq. The research also showed that the spread of humor on Facebook is more than on other social media.

It has been noted that most of the commenters with humorous commenters are young since that older Iraqi commenters tend to comment carefully and seriously.

The analysis of the selected data demonstrated that the maxim of relation was widely followed more than other maxims. Most of the maxims that have not been observed are the maxims of quality. Although many of the humor comments violated some of the maxims, despite this, it clearly conveyed the intended meaning, so that we apply the saying that indicates (we cannot be considered the person who violates the maxims that he does not cooperate just because he or she try to be humorous, Attardo, 2001). As for the most form of non-observance of maxims that was used in selected comments, it is flouting and violating.

The significance of the study lies in that it presents data that are not studied or examined before as it deals with humorous Iraqi comments on one of the most influential internet platforms; Facebook.

To further development of this work, the researcher suggests that it is better to examine the linguistic devices employed by Iraqis when commenting on topics related to celebrities on Instagram.

\section{References}

[1] Attardo, S. (1994). Linguistic Theories of Humor. New York: Mouton de Gruyter.

[2] Attardo, S. (2001). Humor and Irony in Interaction: From Mode Adoption to Failure of Detection. Amsterdam: IOS Press.

[3] Attardo, S. (2017). The general theory of verbal humor. In Attardo, S. (ed.), The Routledge handbook of language and humor. New York and London: Routledge.

[4] Cutting, J. (2002). Pragmatics and Discourse: A Resource Book for Students. London: Routledge.

[5] Freud, S. (1960). Jokes and their relation to the unconscious. London: Routledge \& Paul. ed by the society.

[6] Freud, S. (1976). Jokes and their relation to the unconscious, Penguin, Harmondsworth

[7] Grice, H. P. (1975). Logic and Conversation, in P. Cole. New York: Academic Press.

[8] Hobbes, T. (1962). 'Hunan Nature', in The English Works of Thomas Hobbes, Vol. 4, Scientia Aalen.

[9] Horn, L.R. (2006). The Handbook of Pragmatics. L.R. Horn and G. Ward (eds). Oxford: Blackwell Publishing Ltd.

[10] Martin, R.A. (2007). The Psychology of Humor: An Integrative Approach. Burlington, MA: Elsevier Academic Press.

[11] Plato. (1861). 'Philebus', in The Works of Plato, Vol. 4, Henry Bohn, London.

[12] Raskin, V. (1991). Script theory revised(it)ed: Joke similarity and joke representation model Humor: International Journal of Humor Research.

[13] Schopenhauer, A. (1909). 'On the theory of the ludicrous', in The World as Will and Idea Kegan Paul, London.

[14] Singh, R.K. (2012). Humour, Irony, and Satire in Literature. International Journal of English and Literature, pg. 65-72.

[15] Trask, R.L. 1999. Key Concepts in Language and Linguistics. New York: Routledge.

[16] William J. P and Ropert W. W (1983). Linguistics and Humor. P. E. McGhee et al. (eds.), Handbook of Humor Research, Springer-Verlag New York Inc.

[17] Yule, G. (1996). Pragmatics. Oxford: Oxford University Press. 